\title{
Record of Little Ice Age sea surface temperatures at Bermuda using a growth-dependent calibration of coral $\mathrm{Sr} / \mathrm{Ca}$
}

\author{
Nathalie F. Goodkin and Konrad A. Hughen \\ Department of Marine Chemistry and Geochemistry, Woods Hole Oceanographic Institution, \\ Woods Hole, Massachusetts, USA
}

Anne L. Cohen

Department of Marine Geology and Geophysics, Woods Hole Oceanographic Institution, Woods Hole, Massachusetts, USA

Struan R. Smith ${ }^{1}$

Bermuda Biological Station for Research, Ferry Reach, Bermuda

Received 1 February 2005; revised 18 July 2005; accepted 30 August 2005; published 30 November 2005.

[1] Strontium to calcium ratios $(\mathrm{Sr} / \mathrm{Ca})$ are reported for a massive brain coral Diploria labyrinthiformis collected from the south shore of Bermuda and are strongly correlated with both sea surface temperature (SST) and mean annual skeletal growth rate. High $\mathrm{Sr} / \mathrm{Ca}$ ratios correspond with cold SSTs and slow skeletal growth rate and vice versa. We provide a quantitative calibration of $\mathrm{Sr} / \mathrm{Ca}$ to extension rate and $\mathrm{SST}$ along the axis of maximum growth and derive a growth-dependent $\mathrm{Sr} / \mathrm{Ca}-\mathrm{SST}$ calibration equation to reconstruct western subtropical North Atlantic SSTs for the past 223 years. When the influence of growth rate is excluded from the calibration, $\mathrm{Sr} / \mathrm{Ca}$ ratios yield SSTs that are too cold during cool anomalies and too warm during warm anomalies. Toward the end of the Little Ice Age $(\sim 1850)$, SST changes derived using a calibration that is not growth-dependent are exaggerated by a factor of 2 relative to those from the growth-corrected model that yields SSTs $\sim 1.5^{\circ} \mathrm{C}$ cooler than today. Our results indicate that incorporation of growth rate effects into coral $\mathrm{Sr} / \mathrm{Ca}$ calibrations may improve the accuracy of SSTs derived from living and fossil corals.

Citation: Goodkin, N. F., K. A. Hughen, A. L. Cohen, and S. R. Smith (2005), Record of Little Ice Age sea surface temperatures at Bermuda using a growth-dependent calibration of coral Sr/Ca, Paleoceanography, 20, PA4016, doi:10.1029/2005PA001140.

\section{Introduction}

[2] Accurate estimates of past SSTs, not captured in short instrumental records, are key to understanding long-term variability in Earth's climate system. One method of SST reconstruction is based on the inverse correlation between the $\mathrm{Sr} / \mathrm{Ca}$ content of reef coral skeleton and ocean temperature [Smith et al., 1979]. With this technique, $\mathrm{Sr} / \mathrm{Ca}-\mathrm{SST}$ calibrations derived from living corals are applied to ancient specimens to reconstruct SST [Beck et al., 1992; Correge et al., 2004; Guilderson et al., 1994; McCulloch et al., 1999]. With high accretion rates, longevity, and skeletal annual growth bands, corals can potentially provide seasonally resolved, precisely dated records of SST spanning several centuries. Despite this potential, $\mathrm{Sr} / \mathrm{Ca}$-derived SSTs from ancient corals are often several degrees cooler than those derived from other marine proxies [Lea et al., 2000; Pelejero et al., 1999; Rosenthal et al., 2003] and their accuracy has been questioned [Crowley, 2000].

[3] There are several indications that growth or calcification rate may influence the $\mathrm{Sr} / \mathrm{Ca}$ ratio of coral skeleton.

\footnotetext{
${ }^{1}$ Now at Biology Department, Georgia State University, Atlanta, Georgia, USA.

Copyright 2005 by the American Geophysical Union. 0883-8305/05/2005PA001140\$12.00
}

Across coral taxa, faster growing species have lower $\mathrm{Sr} / \mathrm{Ca}$ ratios than slow growing species [Correge et al., 2004; Weber, 1973]. Within a single species, fast growing colonies often have lower $\mathrm{Sr} / \mathrm{Ca}$ ratios than slow growing colonies or slower growing parts within a colony [Alibert and McCulloch, 1997; Cohen and Hart, 2004; deVilliers et al., 1995]. Corals whose calcification rates are enhanced by symbiont photosynthesis have lower $\mathrm{Sr} / \mathrm{Ca}$ ratios than conspecifics without symbionts [Cohen et al., 2002]. Culture studies demonstrate that differences in ion transport rates during calcification lead to reduced $\mathrm{Sr}$ uptake relative to $\mathrm{Ca}$ during periods of rapid calcification and vice versa [Cohen and McConnaughey, 2003; Ferrier-Pages et al., 2002; Ip and Krishnaveni, 1991]. Hypotheses regarding the mechanisms by which growth may influence coral $\mathrm{Sr} / \mathrm{Ca}$ ratios include sampling artifacts linked to slow growth, convoluted skeletal architecture [Cohen et al., 2004; Swart et al., 2002], and kinetic effects [deVilliers et al., 1994]. To date, effects related to calcification or growth rates have been examined between colonies of the same species [deVilliers et al., 1995], between fast and slow growing axes of the same colony [deVilliers et al., 1994] and between different times in the life of a coral polyp [Alibert and McCulloch, 1997].

[4] Here we present data that demonstrate the impact of variability in skeletal extension rates on the accuracy of $\mathrm{Sr} /$ $\mathrm{Ca}$-based SST reconstructed along a single, fast growing axis of a massive brain coral, Diploria labyrinthiformis. 


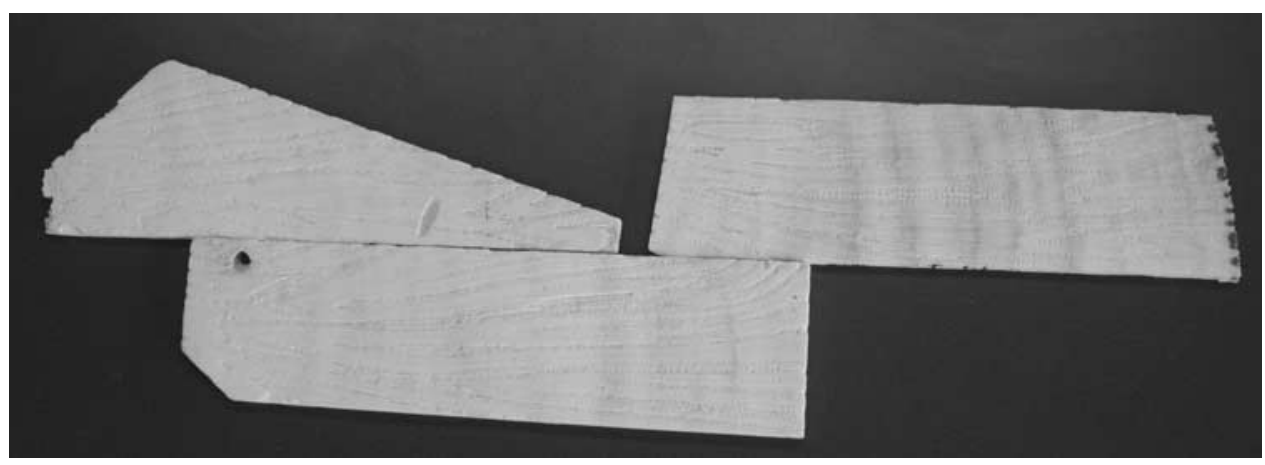

Figure 1. Three 5- to 10-mm-thick slabs were sliced from the $\sim 1-\mathrm{m}$-long coral to capture the major growth axis through time. Slabs were cut in an overlapping fashion to ensure proper age model development and consecutive sampling of the entire record.

Growth rate changes of up to factors of 2-3 are associated with anomalously warm and cool $\mathrm{Sr} / \mathrm{Ca}$-derived SSTs, compared to recorded temperatures. A Sr/Ca-SST calibration that takes growth rate into account shows improved agreement with instrumental SST, and an application of the growth-corrected model yields late Little Ice Age (LIA), $\sim 1850 \mathrm{AD}$, SSTs $1.5^{\circ} \mathrm{C}$ cooler than they are today. In contrast, SSTs derived from $\mathrm{Sr} / \mathrm{Ca}$ while excluding growth rate effects were up to $3.0^{\circ} \mathrm{C}$ cooler than today.

\section{Methods}

\subsection{Study Site}

[5] In May 2000, an 230-year-old massive brain coral colony was sampled live off John Smith's Bay (JSB) on the southeastern edge of the Bermuda platform at 16-m depth. On Bermuda, growth rates of Diploria labyrinthiformis range from 2 to $6 \mathrm{~mm} / \mathrm{yr}$ [Cohen et al., 2004; Dodge and Thomson, 1974; Logan and Tomascik, 1991; Logan et al., 1994], compared to $8 \mathrm{~mm} / \mathrm{yr}$ and up to $20 \mathrm{~mm} / \mathrm{yr}$ in more widely used species such as Porites [Alibert and McCulloch, 1997; Hughen et al., 1999; Mitsuguchi et al., 1996; Shen et al., 1996]. Diploria spp. inhabit a wide range of water temperatures and are found in both the tropical and subtropical Atlantic. While Diploria spp. have not often been widely used for paleoclimate reconstruction [Cardinal et al., 2001; Cohen et al., 2004; Kuhnert et al., 2002] the long life spans and large geographic distribution indicate its promise as a tool for long paleoclimate records.

[6] The south terrace of Bermuda was chosen because of its exposure to open ocean waters and proximity to hydrostation $\mathrm{S}$ located $30 \mathrm{~km}$ to the southeast. SST from 0- to 16-m depth has been recorded at hydrostation S biweekly since 1954 . Over that time, monthly averaged SST ranged from $18.0^{\circ}$ to $28.9^{\circ} \mathrm{C}$ with annual averages between $22.4^{\circ}$ and $24.3^{\circ} \mathrm{C}$. For the calibration period of this study (1976-1997), mean annual SST ranged from $22.8^{\circ}$ to $23.5^{\circ} \mathrm{C}$ with a seasonal range of $18.3^{\circ}$ to $28.9^{\circ} \mathrm{C}$. The SST record is incomplete over different intervals including 2 or more months of missing data in the years 1978-1980, 1986 and 1989.

\subsection{Subsampling and Analysis of Coral}

[7] Three 5- to 10-mm-thick slabs were cut from the maximum growth axis of the coral using a diamond blade rock saw (Figure 1). The slabs were cleaned in an ultrasonic bath with deionized $\mathrm{H}_{2} \mathrm{O} 3$ times for $10 \mathrm{~min}$ and dried in an oven at $50^{\circ} \mathrm{C}$. X-radiographs were performed at Falmouth (Massachusetts) Hospital with machine settings of $50 \mathrm{kV}$ and $1.6 \mathrm{mAs}$, a film focus distance of $1 \mathrm{~m}$ and an exposure time of $0.2 \mathrm{~s}$.

[8] All samples were drilled from the solid thecal wall (the septotheca) that separates the calyx from the ambulacrum [Cohen et al., 2004]. We targeted the theca to ensure that ample material could be extracted for analysis and to diminish the potential for diagenetic alteration or secondary aragonite precipitation due to the isolation of the center of the wall from skeletal pore spaces filled with seawater. In situ staining studies suggest that extension rates on the theca are higher in the summer (June through September) than they are in the winter [Cohen et al., 2004].

[9] Annual extension rates, calculated from the distance between successive high-density bands in the X-radiograph, indicate an average growth rate of $3.8 \mathrm{~mm} / \mathrm{yr}$. From 1976 to 1997, the thecal wall was sampled at $0.33 \mathrm{~mm}$ (approximately monthly resolution) with a drill press and micrometer-controlled stage. Approximately $200 \mu \mathrm{g}$ of powder was collected for each $\mathrm{Sr} / \mathrm{Ca}$ analysis. The years 1775-1997 were sampled biennially, using a diamond blade band saw. To generate the biennial record, samples were cut between every second high- low-density band interface, and the theca was isolated by grinding away the calyx with a hand-held Dremel tool. Thecal samples $(\sim 0.9 \mathrm{~g})$ representing the full 2 years growth were cleaned in an ultrasonic bath with deionized $\mathrm{H}_{2} \mathrm{O} 3$ times for $10 \mathrm{~min}$, and dissolved in $1 \mathrm{~N} \mathrm{HNO}_{3}^{-}$for analysis.

[10] $\mathrm{Sr}$ and $\mathrm{Ca}$ were measured using Inductively Coupled Plasma-Atomic Emission Spectrometry (ICP-AES) applying solution standards to correct for drift and matrix effects related to interference from varying $\mathrm{Ca}$ concentrations [Schrag, 1999]. The samples, blanks, and external standard (a homogenized, powdered Porites coral) were prepared simultaneously. Repeat measurements on the coral external standard over 12 months showed reproducibility $(n=96$, standard deviation $=0.02 \mathrm{mmol} / \mathrm{mol}$ ).

[11] The age model was constructed from density banding visible in the X-radiographs and refined by tuning $\mathrm{Sr} / \mathrm{Ca}$ to monthly averaged SSTs at inflection points. While this lessens the independence of the $\mathrm{Sr} / \mathrm{Ca}-\mathrm{SST}$ relationship, 

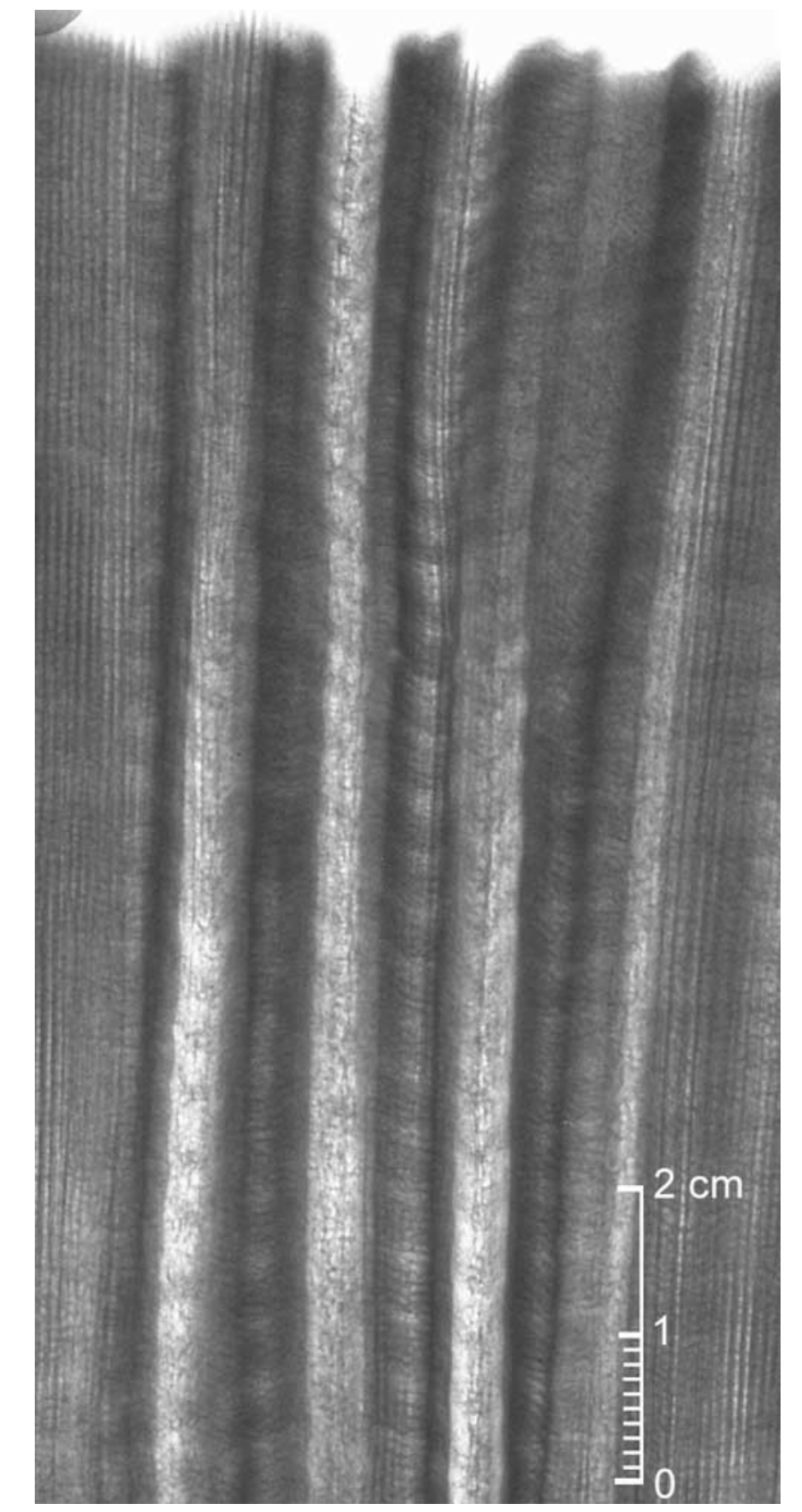

Figure 2. X-radiograph positive image of the first $97 \mathrm{~mm}$ of the top slab. $\mathrm{X}$ rays show clear annual banding made up of one low-density and one high-density band.

maximum and minimum values rather than median values at the inflection points drive the correlation of $\mathrm{Sr} / \mathrm{Ca}$ to SST. $\mathrm{The} \mathrm{Sr} / \mathrm{Ca}$ data were resampled by linear interpolation at even monthly intervals equivalent to SST data.

[12] Reported annual growth (extension) rates for the high-resolution record (approximately monthly sampling) were calculated from the distance between two successive Januarys in each annual cycle as defined by the $\mathrm{Sr} / \mathrm{Ca}-$ derived age model. Growth rates for the biennial record were determined using X-radiographs (Figure 2) as follows; the distance between every other high- low-density band interface was measured and divided in two to calculate the average growth per year over the 2 years sampled.

\section{Results}

\subsection{Reproducibility of the $\mathrm{Sr} / \mathrm{Ca}$ Record Within the Colony}

[13] As this Diploria colony grew, the position of the maximum growth axis changed relative to the center of the dome (Figure 1). Therefore it was difficult for the entire length of the coral to be sampled along one planar growth transect, mandating that sampling transects change between the theca from along the slabs. Parallel transects were drilled for the periods 1979-1986 and 1989-1992. A strong relationship exists between the multiple tracts $\left(\mathrm{r}^{2}=\right.$ $0.83, \mathrm{p}=0$, slope $=1.04$, intercept $=-0.000705)$, demonstrating the reproducibility of the $\mathrm{Sr} / \mathrm{Ca}$ signal between parallel sample transects.

\subsection{Monthly Resolution Calibration}

[14] A linear regression of monthly resolved $\mathrm{Sr} / \mathrm{Ca}$ ratios to SST yields the following correlation (Figure 3a):

$$
\begin{gathered}
\mathrm{Sr} / \mathrm{Ca}=10.1( \pm 0.04)-0.0358( \pm 0.0018) * \mathrm{SST} \\
\left(2 \sigma, 95 \% \text { conf., } \mathrm{r}^{2}=0.86, \mathrm{p} \ll 0.0001, \mathrm{stdr}=1.2^{\circ} \mathrm{C}\right)
\end{gathered}
$$

where stdr is the standard deviation of the residual. These results are consistent with previous studies of slow to moderately slow growing corals, including a colony of Diploria from Bermuda [Cardinal et al., 2001], Montastraea from Florida [Swart et al., 2002], and Diploastrea from Fiji [Bagnato et al., 2004]. On the basis of results from Cohen et al. [2004] using microbeam measurements, our sampling resolution may dampen the full range of $\mathrm{Sr} / \mathrm{Ca}$ variability over the annual cycle. Owing to this smoothing, the monthly calibration cannot be used to reconstruct interannual variability as the dampened slope would return overestimated changes in SST. For this reason, calibrations using interannual variability were derived.

\subsection{Interannual Calibrations}

[15] To derive the $\mathrm{Sr} / \mathrm{Ca}-\mathrm{SST}$ calibrations based on interannual variability, 4-month summer (JJAS), 4-month winter (DJFM), and mean annual averages were calculated. Examination of the monthly $\mathrm{Sr} / \mathrm{Ca}$ calibration (Figure 3a) indicates that summertime $\mathrm{Sr} / \mathrm{Ca}$ reflects SST from 1977 to 1986 differently than from 1987 to 1997, while the wintertime signal continues to capture interannual SST variability. This can be seen clearly when the data are averaged for summer (Figure 3b) and winter (Figure 3c) periods. Coincident with the change in the summer time $\mathrm{Sr} / \mathrm{Ca}-\mathrm{SST}$ relationship is a decrease in the mean annual extension rate from above average to below average for the calibration period (Figures 3b, 3c, and 3d). Average annual SSTs derived from coral $\mathrm{Sr} / \mathrm{Ca}$ are essentially a combination of the summer and winter signals and also diverge from instrumental data at the same time as the decrease in mean annual extension rate (Figure 3d). Average summer $\mathrm{Sr} / \mathrm{Ca}$ 

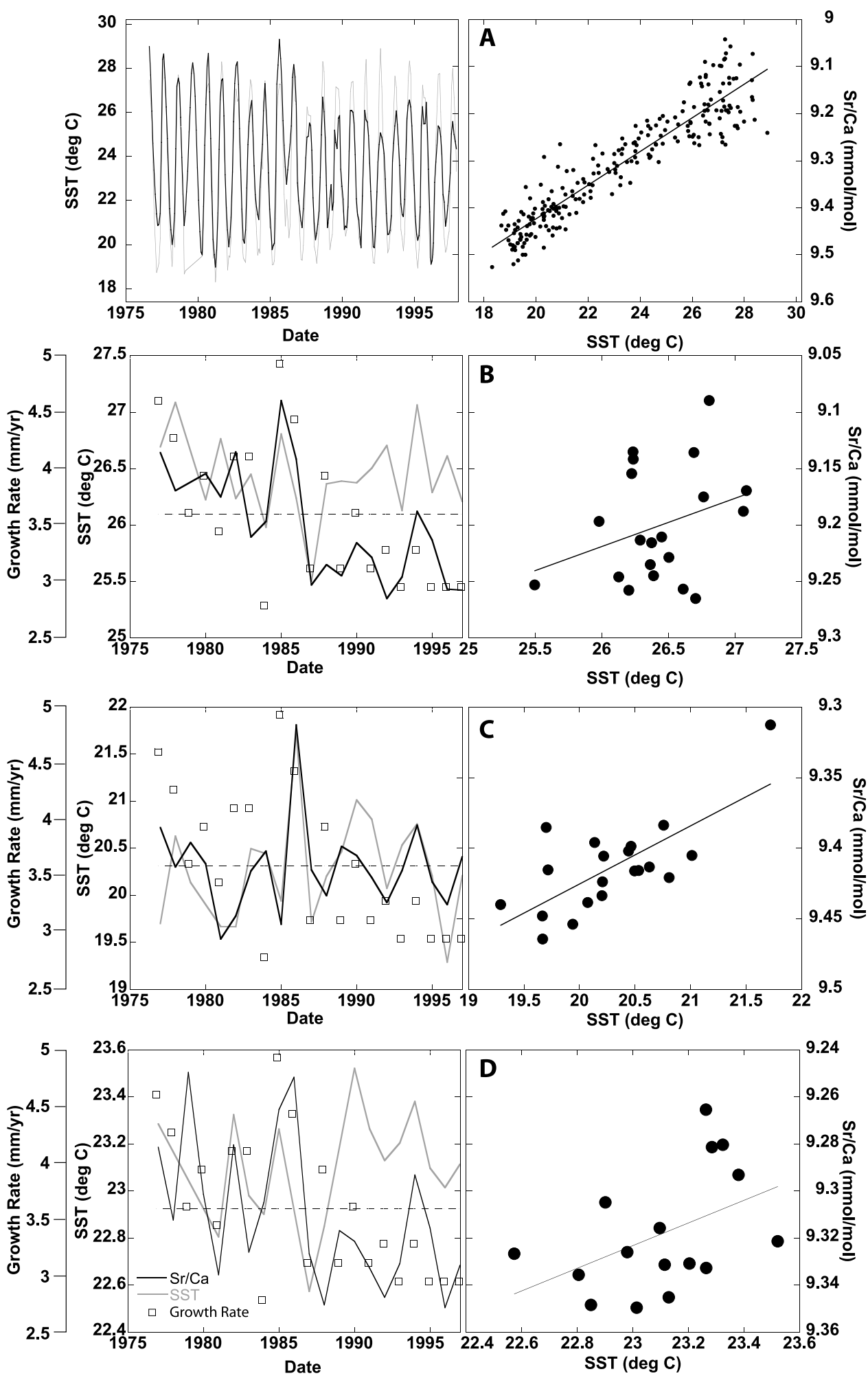

Figure 3. Coral $\mathrm{Sr} / \mathrm{Ca}$ (solid line) and hydrostation $\mathrm{S}$ sea surface temperature (SST) (shaded line) plotted versus year and correlated using linear regression. Calibration results for (a) monthly $\left(r^{2}=0.86, p \ll\right.$ $0.0001)$, (b) summer (June, July, August, September (JJAS)) $\left(r^{2}=0.10, p=0.17\right)$, (c) winter (December, January, February, March (DJFM) $\left(r^{2}=0.51, p=0.0004\right)$, and $(d)$ mean annual $\left(r^{2}=0.21, p=0.077\right)$ resolved data. Mean annual coral growth rates (squares) and average growth (dashed line) are shown for the calibration period. Size of circles represents $2 \sigma$ analytical error. 

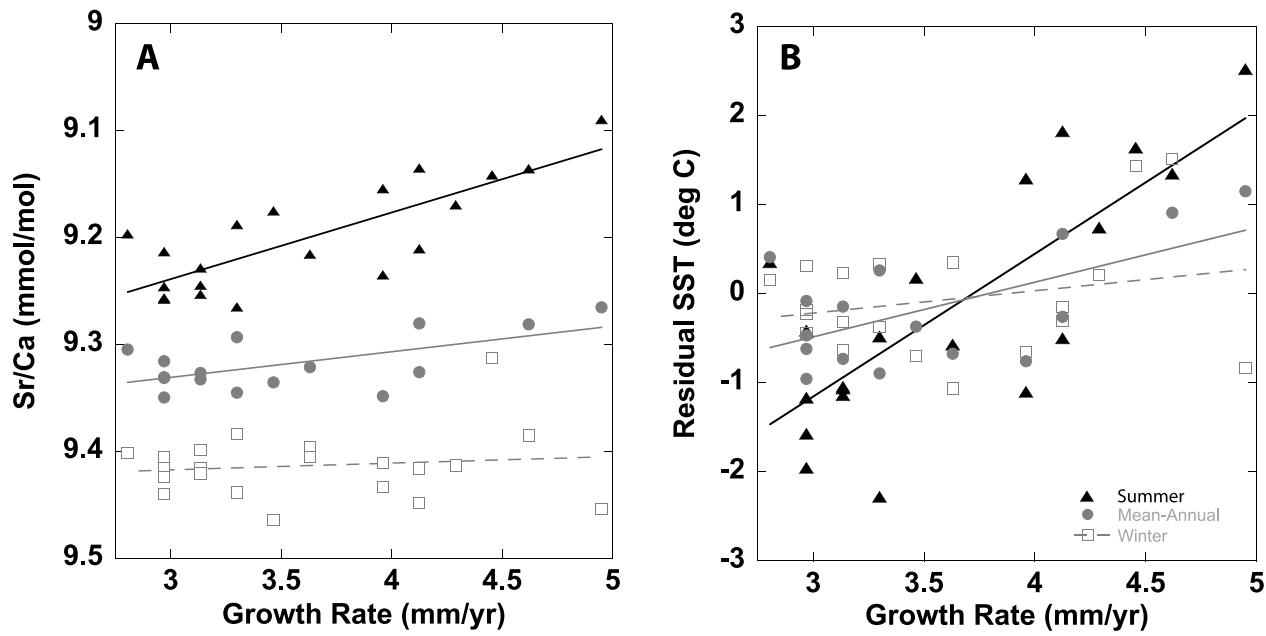

Figure 4. Mean annual growth rate compared to $\mathrm{Sr} / \mathrm{Ca}$ and $\mathrm{Sr} / \mathrm{Ca}$-based $\mathrm{SST}$ residuals. (a) $\mathrm{Sr} / \mathrm{Ca}$ to growth rate correlations for summer (JJAS) (triangles) $\left(\mathrm{r}^{2}=0.64, \mathrm{p}<0.0001\right)$, mean annual $($ circles $)\left(\mathrm{r}^{2}=\right.$ $0.36, \mathrm{p}=0.014)$, and winter (DJFM) (squares) $\left(\mathrm{r}^{2}=0.01, \mathrm{p}=0.61\right)$ resolved data. (b) Residual SST to growth rate correlations for summer $\left(\mathrm{r}^{2}=0.59, \mathrm{p}<0.0001\right)$, mean annual $\left(\mathrm{r}^{2}=0.36, \mathrm{p}=0.013\right)$, and winter $\left(r^{2}=0.06, p=0.31\right)$ resolved data. Residuals are calculated by converting monthly $\mathrm{Sr} / \mathrm{Ca}$ to SST and then subtracting from instrumental SST.

shows no relationship to SST when correlated over the entire 1977-1997 calibration interval $\left(\mathrm{r}^{2}=0.10, \mathrm{p}=0.17\right)$ (Figure $3 \mathrm{~b}$ ), and the mean annual record shows a poor correlation $\left(\mathrm{r}^{2}=0.21, \mathrm{p}=0.077\right)$ (Figure $\left.3 \mathrm{~d}\right)$. Average winter $\mathrm{Sr} / \mathrm{Ca}$ does not show any discrepancy affiliated with growth rate (Figure 3c), and a winter linear least squares regression to SST shows a significant relationship:

$$
\mathrm{Sr} / \mathrm{Ca}=10.3( \pm 0.4)-0.0412( \pm 0.0191) * \mathrm{SST}
$$$$
\left(2 \sigma, 95 \% \text { conf., } \mathrm{r}^{2}=0.51, \mathrm{p}=0.0004, \mathrm{stdr}=0.54^{\circ} \mathrm{C}\right)
$$

The winter correlation $\mathrm{r}^{2}$ value is diminished in comparison with the monthly calibration, because of the lower signal-tonoise ratio (winter $\mathrm{SST}$ range $=19^{\circ}-22^{\circ} \mathrm{C}$, annual $\mathrm{SST}$ range $=18^{\circ}-29^{\circ} \mathrm{C}$ ).

[16] Examination of the relationship between $\mathrm{Sr} / \mathrm{Ca}$ and growth reveals that summer $\mathrm{Sr} / \mathrm{Ca}$ correlates more strongly to annual skeletal extension rate $\left(\mathrm{r}^{2}=0.64, \mathrm{p}<0.0001\right)$ (Figure $4 \mathrm{a})$ than to $\operatorname{SST}\left(\mathrm{r}^{2}=0.10, \mathrm{p}=0.17\right)$. Mean annual $\mathrm{Sr} / \mathrm{Ca}$ correlates relatively equally to growth rate $\left(\mathrm{r}^{2}=0.36\right.$, $\mathrm{p}=0.014)$ and $\operatorname{SST}\left(\mathrm{r}^{2}=0.21, \mathrm{p}=0.077\right)$, whereas winter $\mathrm{Sr} / \mathrm{Ca}$ shows no relationship to growth rate $\left(\mathrm{r}^{2}=0.01, \mathrm{p}=\right.$ $0.61)$ (Figure $4 \mathrm{a})$ and a strong relationship to $\mathrm{SST}\left(\mathrm{r}^{2}=0.51\right.$, $\mathrm{p}=0.0004)$. The impact of growth rate on summer, winter, and mean annual $\mathrm{Sr} / \mathrm{Ca}-\mathrm{SST}$ calibrations is further investigated by correlating growth rate with SST residuals (calculated by subtracting instrumental SST from reconstructed monthly SST). Summer SST residuals are strongly correlated with growth rate $\left(\mathrm{r}^{2}=0.59, \mathrm{p}<0.0001\right)$, but no significant relationship is observed between growth rate and winter SST residuals $\left(\mathrm{r}^{2}=0.06, \mathrm{p}=0.31\right)$ (Figure $\left.4 \mathrm{~b}\right)$. Mean annual SST residuals show a correlation with growth rate $\left(\mathrm{r}^{2}=0.37, \mathrm{p}=\right.$ 0.013 ) that is better than the winter residual $\mathrm{Sr} / \mathrm{Ca}$ regression but not as good as the summer residual $\mathrm{Sr} / \mathrm{Ca}$ regression (Figure $4 \mathrm{~b}$ ). Thus averaging over the annual cycle does not eliminate the impact of growth rate on $\mathrm{Sr} / \mathrm{Ca}$ signals, implying that a growth-corrected model must be employed to examine interannual variability.

[17] In the mean annual $\mathrm{Sr} / \mathrm{Ca}$ regression, mean annual $\mathrm{Sr} /$ $\mathrm{Ca}$ was linearly regressed on mean annual SST by the preceding equation (Figure $3 \mathrm{~d}$ ):

$$
\mathrm{Sr} / \mathrm{Ca}=\mathrm{m} * \mathrm{SST}+\mathrm{b}
$$

This regression produced the following result:

$$
\begin{gathered}
\mathrm{Sr} / \mathrm{Ca}=10.4( \pm 1.2)-0.0481( \pm 0.0503) * \mathrm{SST} \\
\left(2 \sigma, 95 \% \text { conf. }, \mathrm{r}^{2}=0.21, \mathrm{p}=0.0766, \mathrm{stdr}=0.46^{\circ} \mathrm{C}\right)
\end{gathered}
$$

In the growth-corrected mean annual model, the slope (m) of the mean annual $\mathrm{Sr} / \mathrm{Ca}-\mathrm{SST}$ relationship (equation (3)) is hypothesized to change as a linear function of growth rate where

$$
\mathrm{m}=\mathrm{n} *(\text { growth rate })+\mathrm{c}
$$

and growth rate is the 3 -year averaged linear extension rate. The net regressed equation is

$$
\mathrm{Sr} / \mathrm{Ca}=\mathrm{c} *(\mathrm{SST})+\mathrm{n} *(\text { growth rate }) *(\mathrm{SST})+\mathrm{b}
$$

For the purposes of the growth-corrected model, growth rates were averaged over 3 -year periods, providing a more conservative estimate of the continuous calcification rates 


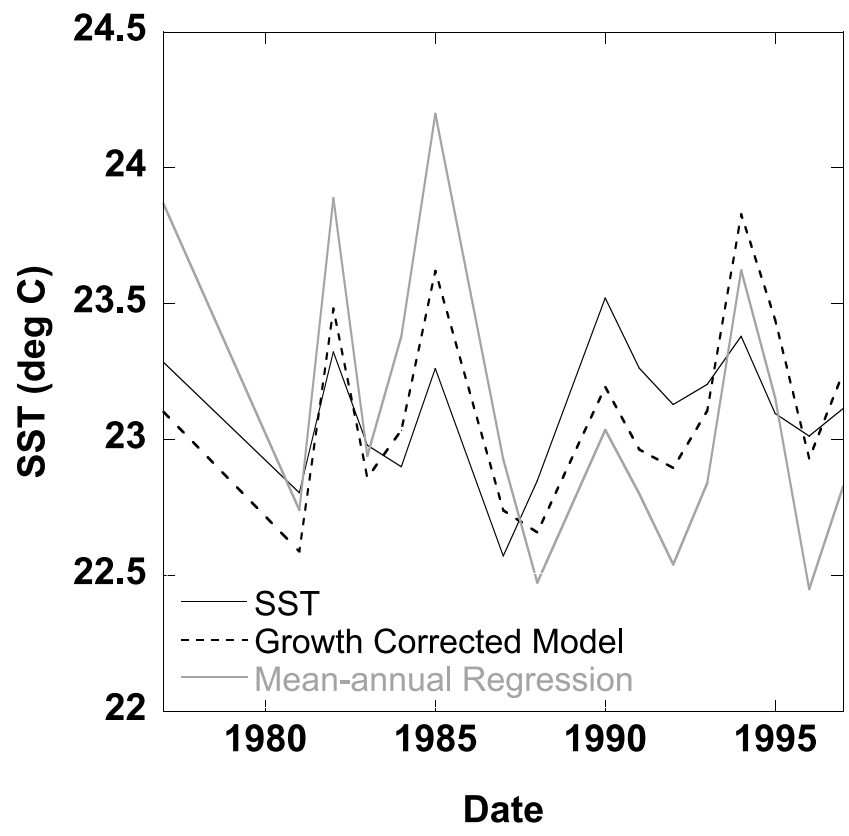

Figure 5. Mean annual instrumental SST from hydrostation $\mathrm{S}$ (solid line) compared to reconstructed mean annual SST using the mean annual $\mathrm{Sr} / \mathrm{Ca}-\mathrm{SST}$ regression (shaded line) and growth-corrected model (dashed line). The growth-corrected model has a stronger fit to the instrumental records $\left(\mathrm{r}^{2}=0.49, \mathrm{p}=0.0026\right.$ compared to $\mathrm{r}^{2}=0.21$, $\mathrm{p}=0.077$ for the nonmean annual $\mathrm{Sr} / \mathrm{Ca}-\mathrm{SST}$ regression).

that occurred as the aragonite was formed by both extension and infilling for the time represented by sampling methods. The linear least squares multiple regression returns the following equation:

$$
\begin{aligned}
& \mathrm{Sr} / \mathrm{Ca}=-0.0529( \pm 0.0334) *(\mathrm{SST}) \\
&-0.00170( \pm 0.00078) *(\text { growth rate }) *(\mathrm{SST}) \\
&+10.7( \pm 0.8) \\
&\left(2 \sigma, 95 \% \text { conf. }, \mathrm{r}^{2}=0.68, \mathrm{p}_{\mathrm{c}}=0.0074\right. \\
&\left.\mathrm{p}_{\mathrm{n}}=0.00078, \mathrm{stdr}=0.24^{\circ} \mathrm{C}\right)
\end{aligned}
$$

where $p_{c}$ is the significance on slope $c$ from equation (6) and $\mathrm{p}_{\mathrm{n}}$ is the significance on slope $\mathrm{n}$ from equation (6). The inclusion of this additional relationship into the growthcorrected model leads to a significant improvement in fit $\left(\mathrm{r}^{2}=\right.$ $\left.0.68, \mathrm{p}_{\mathrm{c}}=0.0074, \mathrm{p}_{\mathrm{n}}=0.00078\right)$ compared to the mean annual $\mathrm{Sr} / \mathrm{Ca}-\mathrm{SST}$ regression $\left(\mathrm{r}^{2}=0.21, \mathrm{p}=0.077\right)$. While the variance of the two fits are not comparable because of the change in the number of variables, mean annual $\mathrm{Sr} / \mathrm{Ca}$ values over the calibration period were converted to SST using the mean annual $\mathrm{Sr} / \mathrm{Ca}-\mathrm{SST}$ regression and the growth-corrected model to demonstrate the improved accuracy in reconstructing SST. SSTs reconstructed with the growth-corrected model agree more closely with instrumental data $\left(\mathrm{r}^{2}=0.49, \mathrm{p}=\right.$ 0.0026) than those with the mean annual $\mathrm{Sr} / \mathrm{Ca}-\mathrm{SST}$ regression $\left(\mathrm{r}^{2}=0.21, \mathrm{p}=0.077\right)$ (Figure 5). This improvement is exemplified by a decrease in the variance of the residual where the standard deviation equals $0.46^{\circ} \mathrm{C}$ in the $\mathrm{Sr} / \mathrm{Ca}-\mathrm{SST}$ regression compared to $0.24^{\circ} \mathrm{C}$ in the growth-corrected model (Figure 5).

\subsection{Application of Calibration Regressions}

[18] In order to examine the potential effects of the different calibrations on paleotemperature reconstructions, the monthly, mean annual $\mathrm{Sr} / \mathrm{Ca}-\mathrm{SST}$ regression and growth-corrected mean annual model were used to quantify SST from the 223-year biennially sampled $\mathrm{Sr} / \mathrm{Ca}$ record. Reconstructed SST shows distinct cooling during the LIA, with an abrupt temperature drop in the 1840s and a gradual warming culminating in the 1960s. However, the amplitude of these changes varies significantly depending on which calibration is applied.

[19] The reconstruction based on the monthly calibration shows that biennial SST changed nearly $5^{\circ} \mathrm{C}$ from 1960 to the end of the LIA in the late $1840 \mathrm{~s}, 2.5$ times the change found using the growth-corrected mean annual model (Figure 6). The use of a monthly resolved calibration which does not capture the full amplitude of the seasonal cycle clearly influences the magnitude of interannual SST change calculated back through time. The biennial record does not necessarily capture the exact same months in each sample through time which may lead to some seasonal biases. However, this effect is diminished by looking at 2-year periods and is likely not large enough to account for the changes in temperature seen in this record.

[20] The mean annual extension rate of the coral is shown to covary with the $\mathrm{Sr} / \mathrm{Ca}$ record over the length of the

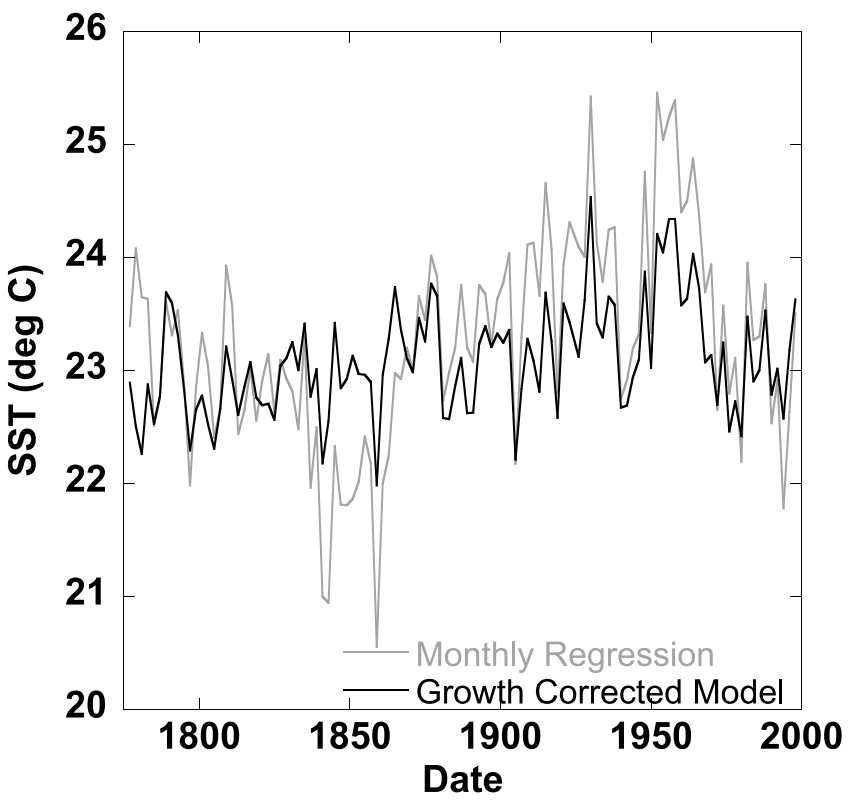

Figure 6. Biennial-resolution SST reconstructed to 1780. SST was reconstructed using the growth-corrected mean annual model (solid line) and the monthly regression (shaded line). By exaggerating both maximums and minimums, the monthly regression shows an SST change 2.5 times greater than the growth-corrected mean annual model reconstruction. 


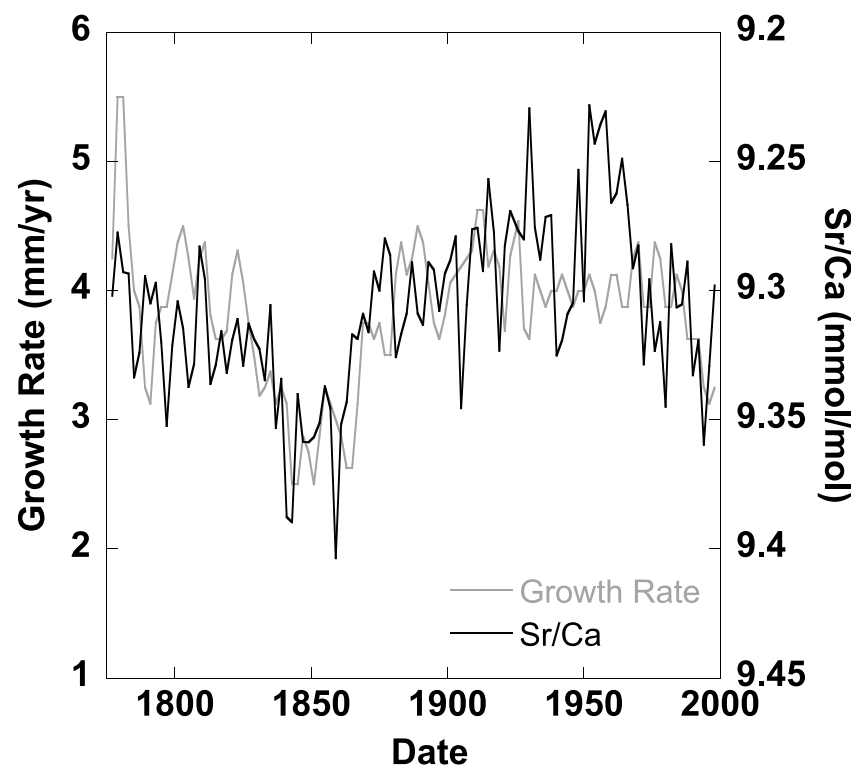

Figure 7. Biennially average mean annual extension (growth) rate (shaded line) and $\mathrm{Sr} / \mathrm{Ca}$ (solid line) from 1780 to 1997. Extension rate and $\mathrm{Sr} / \mathrm{Ca}$ have the same largescale variability patterns over the entire 200 -year period $\left(\mathrm{r}^{2}=0.32, \mathrm{p} \ll 0.0001\right)$.

biennial record, supporting the initial observation that both growth and SST may influence the $\mathrm{Sr} / \mathrm{Ca}$ record (Figure 7). The highest mean annual $\mathrm{Sr} / \mathrm{Ca}$ values seen in the mid-tolate 1800s are also the periods of slowest growth. Use of the mean annual $\mathrm{Sr} / \mathrm{Ca}-\mathrm{SST}$ regression yields an SST change of $3.5^{\circ} \mathrm{C}$ from the $1960 \mathrm{~s}$ to the $1840 \mathrm{~s}$, whereas the growthcorrected model shows a change of only $2^{\circ} \mathrm{C}$ over this same period (Figure 8).

\subsection{Temperature Trends at Bermuda}

[21] The biennially growth-corrected reconstruction agrees with both hydrostation $\mathrm{S}$ and other long coral records from this site. Hydrostation S shows a nearly $2^{\circ} \mathrm{C}$ cooling from the late 1950 s to the late 1960 s, simultaneous with the cooling in this record. In coral growth rate records from Bermuda [Patzold and Wefer, 1992], growth rate is correlated to SST and shows a $>2{ }^{\circ} \mathrm{C}$ temperature change from approximately the late 1800 s to the 1950 s consistent with the growth-corrected biennial $\mathrm{Sr} / \mathrm{Ca}$ record over the same period. A coral $\delta^{18} \mathrm{O}$ record from Bermuda shows a similar trend, with an abrupt cooling around 1840 followed by a slow warming coming out of the end of the Little Ice Age [Draschba et al., 2000].

[22] LIA temperature changes at Bermuda have also been investigated using $\delta^{18} \mathrm{O}$ of foraminifera [Keigwin, 1996] and the alkenone unsaturation index, $\mathrm{U}_{37}^{\mathrm{k}^{\prime}}$ [Ohkouchi et al., 2002; Sachs and Lehman, 1999]. Unfortunately, foraminiferal $\delta^{18} \mathrm{O}$ is influenced both by temperature and the $\delta^{18} \mathrm{O}$ of water, which is a function of salinity. Keigwin [1996] addressed this problem by assuming that the modern salinity and temperature relationship remained constant back in time, and reconstructed an SST change in the Sargasso Sea back to the middle of the LIA of $1^{\circ}-2^{\circ} \mathrm{C}$. The unsaturation index of alkenones provides an SST proxy that is unaffected by water chemistry [Sikes and Sicre, 2002] and has been used to reconstruct abrupt shifts in SST at this location [Sachs and Lehman, 1999]. However, $\mathrm{U}_{37}^{\mathrm{k}^{\prime}}$ reconstructions of LIA SSTs are much larger $\left(4^{\circ}-6^{\circ} \mathrm{C}\right)$ than suggested by foraminiferal $\delta^{18} \mathrm{O}$, and compound specific ${ }^{14} \mathrm{C}$ dating of these alkenones shows they are susceptible to resuspension and long distance transport [Ohkouchi et al., 2002], rendering $\mathrm{U}_{37}^{\mathrm{k}^{9}}$ LIA reconstructions at this location suspect. Our growth-corrected calibration also provides an SST reconstruction not influenced by salinity, yielding late LIA cooling of $1.5^{\circ} \mathrm{C}$. Overall, our data show that application of a $\mathrm{Sr} / \mathrm{Ca}-\mathrm{SST}$ calibration that takes growth rate variations into account yields coral-based SSTs in good agreement with the instrumental record (Figure 5) and with foraminiferal $\delta^{18} \mathrm{O}$ SST estimates [Keigwin, 1996].

\section{Discussion}

[23] While our data support previous observations of growth-related impacts on coral $\mathrm{Sr} / \mathrm{Ca}$, the underlying mechanism, a sampling artifact [Swart et al., 2002], a growth regime [Cohen et al., 2004], or a kinetic effect [deVilliers et al., 1994], is not clear. Microscale analyses of Diploria labyrinthiformis reveal that the amplitude of the annual $\mathrm{Sr} / \mathrm{Ca}$ cycle is greater than that derived by these sampling techniques [Cohen et al., 2004]. Bulk sampling of insufficient resolution smoothes the record as previously suggested [Swart et al., 2002], even though in this study relative winter variability is accurately captured. Examination of the high- and low-density bands in the coral X rays and duration of summer and winter in the $\mathrm{Sr} / \mathrm{Ca}$ seasonal cycle shows that winter skeletal extension is consistent from

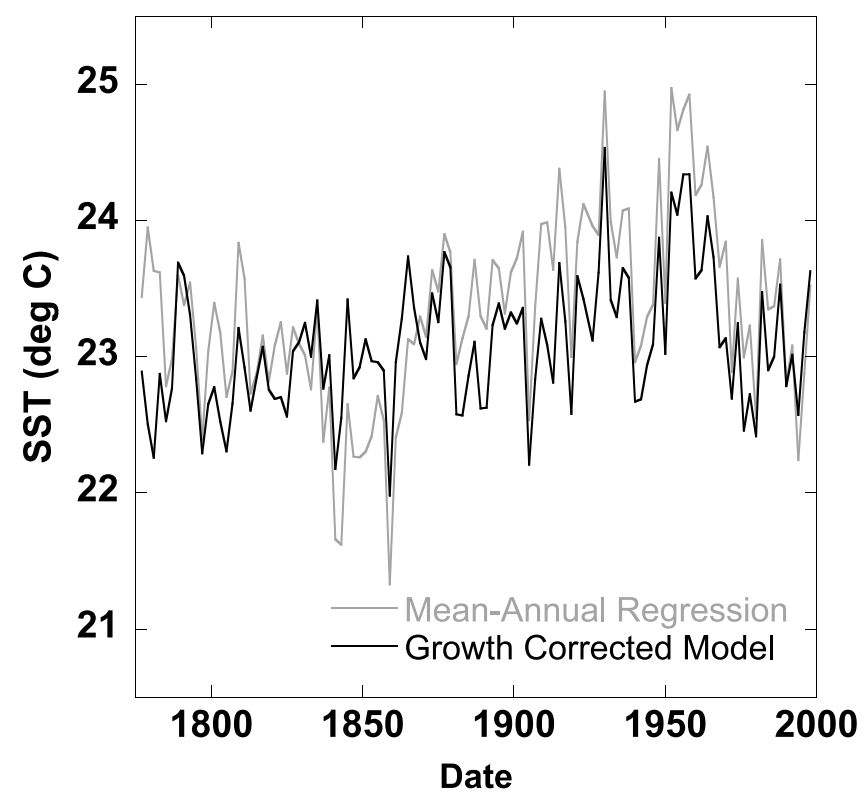

Figure 8. Biennial-resolution SST reconstructed to 1780 . SST reconstructed using the growth-corrected model (solid line), as shown in Figure 4, compared to SST, reconstructed using the mean annual $\mathrm{Sr} / \mathrm{Ca}-\mathrm{SST}$ regression (shaded line). The mean annual $\mathrm{Sr} / \mathrm{Ca}-\mathrm{SST}$ regression exaggerates SST changes from maximum to minimum by a factor of 2 . 
year to year, compared to more variable summer extension. This could lead to a consistent attenuation of the record during sampling of winter skeleton but variable attenuation of summer skeleton, creating the observed growth impact on the summer record but not the winter. Swart et al. [2002] show similar results in a 2-year calibration study in which one summer peak has an average growth rate (during the peak) of $>8 \mathrm{~mm} / \mathrm{yr}$ and $\mathrm{Sr} / \mathrm{Ca}$ values that match the SST maximum, but the second and third summers with lower summer growth rates $(<7 \mathrm{~mm} / \mathrm{yr}$ and $<6 \mathrm{~mm} / \mathrm{yr}$ during the peak) have $\mathrm{Sr} / \mathrm{Ca}$ values that do not reflect the same magnitude summertime SST. These data clearly support an influence of growth rate on the summer $\mathrm{Sr} / \mathrm{Ca}-\mathrm{SST}$ relationship. Similarly, in studies by deVilliers et al. [1994] and Alibert and McCulloch [1997], $\mathrm{Sr} / \mathrm{Ca}$ values associated with relatively slow growth and calcification rates are elevated relative to those from high growth rate and calcification rate intervals. However, in both studies, the records with slower growth or calcification rates appear offset rather than dampened, inconsistent with bulk-sample smoothing as the sole mechanism.

[24] Another hypothesis for the impact of growth on coral $\mathrm{Sr} / \mathrm{Ca}$ is that different growth mechanisms employed by this coral in the summer and winter may influence the $\mathrm{Sr} / \mathrm{Ca}$ signal. Cohen et al. [2004] proposed that skeleton accreted during the summer is overlain by skeleton accreted during the following winter, dampening the summer peak in reconstructed SSTs. Thus the extent of dampening may differ from year to year depending on whether summer extension is slow or fast and the ratio of summer to winter skeleton is shifted.

[25] Coral culture studies indicate that uptake of $\mathrm{Sr}$ relative to $\mathrm{Ca}$ might increase at low calcification rates, increasing the $\mathrm{Sr} / \mathrm{Ca}$ ratio of the skeleton [Ferrier-Pages et al., 2002; Ip and Krishnaveni, 1991] which implies the existence of a kinetic effect. Potential evidence supporting a combined growth regime and kinetic effect is seen in the need to average extension rates over 3 years to fully capture the growth effect in our study. Because in-filling may occur within the skeleton for several years, aragonite laid down in the same location will reflect different calcification rates. By averaging the extension rates (effectively a measure of calcification through time) over 3 years, a better estimate of the average calcification rate over the period of skeletal accretion is achieved and allows for the development of the growth-corrected model. Further study of $\mathrm{Sr} / \mathrm{Ca}$ measurements in conjunction with specific calcification rates could further elucidate the viability of this hypothesis. Indepen- dent of the mechanism by which coral growth rate affects $\mathrm{Sr} / \mathrm{Ca}$, our data show that changes in growth rate along the axis of maximum growth may cause large excursions in $\mathrm{Sr} /$ $\mathrm{Ca}$ that do not accurately reflect the SSTs experienced by the coral.

\section{Conclusions}

[26] The use of a monthly resolved $\mathrm{Sr} / \mathrm{Ca}-\mathrm{SST}$ calibration to reconstruct biennial temperature records appears to cause exaggeration of decadal SST variability over the end of the LIA by a factor of 2.5. This demonstrates the importance of using calibrations that are appropriate to the desired resolution of temperature reconstructions to prevent such amplification of signals, especially if the full seasonal range of $\mathrm{Sr} / \mathrm{Ca}$ variability is not captured by bulk sampling techniques. However, the mean annual $\mathrm{Sr} / \mathrm{Ca}-\mathrm{SST}$ regression also exaggerates SST variability by as much as a factor of 2, demonstrating that growth rate variability can also amplify variations in the $\mathrm{Sr} / \mathrm{Ca}$ reconstructions of temperature. While growth effects are more often referenced for slower growing species such as Diploria, the more commonly studied genera Porites show that interannual growth rates between colonies and within single sampling transects, can vary by factors of 2-2.8 [Alibert and McCulloch, 1997; Hughen et al., 1999; Mitsuguchi et al., 1996; Shen et al., 1996], comparable to the range observed here. It is possible that the influence of growth rate effects on $\mathrm{Sr} / \mathrm{Ca}-\mathrm{SST}$ calibrations could explain previous coral-based SST reconstructions back in time showing larger SST changes [Beck et al., 1997; Correge et al., 2004; Guilderson et al., 1994; McCulloch et al., 1996] than seen with other proxies [Lea et al., 2000; Pelejero et al., 1999; Rosenthal et al., 2003; Rühlemann et al., 1999]. The quantitative incorporation of growth rate information into coral $\mathrm{Sr} / \mathrm{Ca}$ reconstructions could improve the thermometer and result in more accurate estimates of past SST changes and should therefore be considered when undertaking site and species specific calibrations where growth rate data are available.

[27] Acknowledgments. We are indebted to Mike McCartney (M.S.M.) for his support and to G. Webster, S. du Putron, G. Piniak, J. Pitt, A. Solow, D. Schrag, E. Boyle, C. Bertrand, P. Landry, and R. Kayser for logistical and technical help. The in-depth comments and suggestions of one anonymous reviewer and J. Cole significantly improved the original manuscript. A Stanley Watson Foundation Fellowship (N.F.G.), and grants from NSF (OCE-0402728) and WHOI (K.A.H., A.L.C., and M.S.M.) supported this work. This is WHOI contribution 11246.

\section{References}

Alibert, C., and M. T. McCulloch (1997), Strontium/calcium ratios in modern Porites corals from the Great Barrier Reef as a proxy for sea surface temperature: Calibration of the thermometer and monitoring of ENSO, Paleoceanography, 12(3), 345-363.

Bagnato, S., B. K. Linsley, S. S. Howe, G. M. Wellington, and J. Salinger (2004), Evaluating the use of the massive coral Diploastrea heliopora for paleoclimate reconstruction, Paleo- ceanography, 19, PA1032, doi:10.1029/ 2003PA000935.

Beck, J. W., et al. (1992), Sea-surface temperature from coral skeletal strontium calcium ratios, Science, 257(5070), 644-647.

Beck, J. W., J. Recy, F. Taylor, R. L. Edwards, and G. Cabioch (1997), Abrupt changes in early Holocene tropical sea surface temperature derived from coral records, Nature, 385, $705-707$.
Cardinal, D., B. Hamelin, E. Bard, and J. Patzold (2001), $\mathrm{Sr} / \mathrm{Ca}, \mathrm{U} / \mathrm{Ca}$ and $\delta^{18} \mathrm{O}$ records in recent massive corals from Bermuda: Relationships with sea surface temperature, Chem. Geol., 176(1-4), 213-233.

Cohen, A. L., and S. R. Hart (2004), Deglacial sea surface temperatures of the western tropical Pacific: A new look at old coral, Paleoceanography, 19, PA4031, doi:10.1029/ 2004PA001084. 
Cohen, A. L., and T. A. McConnaughey (2003), Geochemical perspectives on coral mineralization, in Biomineralization, Rev. Mineral. Geochem., vol. 54, edited by P. M. Dove, J. J. De Yoreo, and S. Weiner, pp. 151-187, Mineral. Soc. of Am., Washington, D. C.

Cohen, A. L., K. E. Owens, G. D. Layne, and N. Shimizu (2002), The effect of algal symbionts on the accuracy of $\mathrm{Sr} / \mathrm{Ca}$ paleotemperatures from coral, Science, 296(5566), 331-333.

Cohen, A. L., S. R. Smith, M. S. McCartney, and J. van Etten (2004), How brain corals record climate: An integration of skeletal structure, growth and chemistry of Diploria labyrinthiformis from Bermuda, Mar. Ecol. Prog. Ser., 271, 147-158.

Correge, T., et al. (2004), Interdecadal variation in the extent of South Pacific tropical waters during the Younger Dryas event, Nature, 428, 927-929.

Crowley, T. J. (2000), CLIMAP SSTs re-revisited, Clim. Dyn., 255(16), 241-255.

deVilliers, S., G. T. Shen, and B. K. Nelson (1994), The Sr/Ca-temperature relationship in coralline aragonite - Influence of variability in $(\mathrm{Sr} / \mathrm{Ca})$ seawater and skeletal growth-parameters, Geochim. Cosmochim. Acta, 58(1), 197-208.

deVilliers, S., B. K. Nelson, and A. R. Chivas (1995), Biological-controls on coral $\mathrm{Sr} / \mathrm{Ca}$ and $\delta^{18} \mathrm{O}$ reconstructions of sea-surface temperatures, Science, 269(5228), 1247-1249.

Dodge, R. E., and J. Thomson (1974), The natural radiochemical and growth records in contemporary hermatypic corals from the Atlantic and Caribbean, Earth Planet. Sci., Lett., 23, $313-322$.

Draschba, J., J. Patzold, and G. Wefer (2000), North Atlantic climate variability since ad 1350 recorded in $\delta^{18} \mathrm{O}$ and skeletal density of Bermuda corals, Int. J. Earth Sci., 88, 733741.

Ferrier-Pages, C., F. Boisson, D. Allemand, and E. Tambutte (2002), Kinetics of strontium uptake in the scleractinian coral Stylophora pistillata, Mar. Ecol. Prog. Ser., 245, $93-100$.

Guilderson, T. P., R. G. Fairbanks, and J. L. Rubenstone (1994), Tropical temperaturevariations since 20,000 years ago: Modulating interhemispheric climate change, Science, 263(5147), 663-665.

Hughen, K. A., D. P. Schrag, S. B. Jacobsen, and W. Hantoro (1999), El Niño during the last interglacial period recorded by a fossil coral from Indonesia, Geophys. Res. Lett., 26(20), $3129-3132$.

Ip, Y. K., and P. Krishnaveni (1991), Incorporation of strontium $(90 \mathrm{sr} 2+)$ into the skeleton of the hermatypic coral GalaxeaFascicularis, J. Exp. Zool., 258(2), $273-$ 276.

Keigwin, L. D. (1996), The Little Ice Age and Medieval warm period in the Sargasso Sea, Science, 274(5292), 1504-1508.

Kuhnert, H., J. Patzold, B. Schnetger, an G. Wefer (2002), Sea-surface temperature variability in the 16th century at Bermuda inferred from coral records, Palaeogeogr Palaeoclimatol. Palaeoecol., 179(3-4), 159-171.

Lea, D. W., D. K. Pak, and H. J. Spero (2000), Climate impact of the late Quaternary equatorial Pacific sea surface temperature variations, Science, 289(5485), 1719-1724.

Logan, A., and T. Tomascik (1991), Extension growth rates in two coral species from highlatitude reefs of Bermuda, Coral Reefs, 10 , $155-160$.

Logan, A., L. Yang, and T. Tomascik (1994), Linear skeletal extension rates in two species of Diploria from high-latitude reefs in Bermuda, Coral Reefs, 13, 225-230

McCulloch, M., et al. (1996), High resolution windows into early Holocene climate: $\mathrm{Sr} / \mathrm{C}$ coral records from the Huon Peninsula, Earth Planet. Sci. Lett., 138, 169-178.

McCulloch, M. T., et al. (1999), Coral record of equatorial sea-surface temperatures during the penultimate deglaciation at Huon Peninsula, Science, 283(5399), 202-204.

Mitsuguchi, T., E. Matsumoto, O. Abe, T. Uchida, and P. J. Isdale (1996), $\mathrm{Mg} / \mathrm{Ca}$ thermometry in coral skeletons, Science, 274(5289), 961 963.

Ohkouchi, N., T. I. Eglinton, L. D. Keigwin, an J. M. Hayes (2002), Spatial and temporal offsets between proxy records in a sediment drift, Science, 298(5596), 1224-1227.

Patzold, J., and G. Wefer (1992), Bermuda coral reef record of the last 1000 years, paper presented at Fourth International Conference on Paleoceanography, Int. Conf. Paleoceanogr., Kiel, Germany, 21-25 Sept.

Pelejero, C., J. O. Grimalt, S. Heilig, M. Kienast, and L. Wang (1999), High-resolution $U_{37}^{K}$ temperature reconstruction in the South China Sea over the past $220 \mathrm{kyr}$, Paleoceanography, 14(2), 224-231.
Rosenthal, Y., D. W. Oppo, and B. K. Linsley (2003), The amplitude and phasing of climate change during the last deglaciation in the Sulu Sea, western equatorial Pacific, Geophys. Res Lett., $30(8), 1428$, doi:10.1029/ 2002GL016612.

Rühlemann, C., S. Mulitza, P. J. Müller, G. Wefer, and R. Zahn (1999), Warming of the tropical Atlantic Ocean and slowdown of thermohaline circulation during the last deglaciation, Nature, 402, 511-514.

Sachs, J. P., and S. Lehman (1999), Subtropical North Atlantic temperatures 60,000 to 30,000 years ago, Science, 286(5440), $756-759$.

Schrag, D. P. (1999), Rapid analysis of high-precision $\mathrm{Sr} / \mathrm{Ca}$ ratios in corals and other marine carbonates, Paleoceanography, 14(2), $97-$ 102.

Shen, C. C., et al. (1996), The calibration of D $\mathrm{Sr} / \mathrm{Ca}$ versus sea surface temperature relationship for Porites corals, Geochim. Cosmochim. Acta, 60(20), 3849-3858.

Sikes, E. L., and M.-A. Sicre (2002), Relationship of the tetra-unsaturated $\mathrm{C}_{37}$ alkenone to salinity and temperature: Implications for paleoproxy applications, Geochem. Geophys. Geosyst., 3(11), 1063, doi:10.1029/ $2002 \mathrm{GC} 000345$.

Smith, S. V., R. W. Buddemeier, R. C. Redalje, and J. E. Houck (1979), Strontium-calcium thermometry in coral skeletons, Science, 204(4391), 404-407.

Swart, P. K., H. Elderfield, and M. J. Greaves (2002), A high-resolution calibration of $\mathrm{Sr} / \mathrm{Ca}$ thermometry using the Caribbean coral Montastraea annularis, Geochem. Geophys. Geosyst., 3(11), 8402, doi:10.1029/ 2002GC000306.

Weber, J. N. (1973), Incorporation of strontium into reef coral skeletal carbonate, Geochim. Cosmochim. Acta, 37(9), 2173-2190.

A. L. Cohen, Department of Marine Geology and Geophysics, Woods Hole Oceanographic Institution, Woods Hole, MA 02543, USA.

N. F. Goodkin and K. A. Hughen, Department of Marine Chemistry and Geochemistry, Woods Hole Oceanographic Institution, Woods Hole, MA 02543, USA. (ngoodkin@whoi.edu)

S. R. Smith, Biology Department, Georgia State University, P. O. Box 4010, Atlanta, GA 30302-4010, USA. 